\title{
Prioritization of treatment: need- or desire-based approach with a three-year follow-up
}

\author{
D Divekar
}

From 5th International Conference on Ectodermal Dysplasia (ED2012)

Erlangen, Germany. 1-3 June 2012

In general, medical teams do not prioritize treatment in a way to establish mental health prior to other parts of a treatment sequence. Patients with ectodermal dysplasia may not be compromised systemically, but mentally they surely are. In cases of ectodermal dysplasia, the psychological inadequacy may be attributed to the characteristic facial appearance and the absence of teeth. Such cases can be better managed by prioritizing treatment, choosing a desire-based approach rather than a needbased course of action. Improving the facial appearance first will strengthen the confidence of the patient in the operator and increase his overall acceptance in the society. Overcoming psychological barriers allows intraoral rehabilitation with lesser effort and increases its success.

Published: 25 May 2012

Submit your next manuscript to BioMed Central and take full advantage of:

- Convenient online submission

- Thorough peer review

- No space constraints or color figure charges

- Immediate publication on acceptance

- Inclusion in PubMed, CAS, Scopus and Google Scholar

- Research which is freely available for redistribution 